\title{
Ecological network analysis to link interactions between system components and performances in multispecies livestock farms
}

\author{
Lucille Steinmetz $^{1}$ (D) $\cdot$ Patrick Veysset $^{1} \cdot$ Marc Benoit $^{1} \cdot$ Bertrand Dumont $^{1}$
}

Accepted: 19 April 2021 / Published online: 28 May 2021

(C) The Author(s) 2021

\begin{abstract}
Organic farming relies on ecological processes to replace chemical inputs, and organic farmers have developed various strategies, including several forms of diversification, to remain viable. Herein, we hypothesized that diversified organic farming systems can enhance their performance by increasing the level of interactions between system components. We therefore performed an ecological network analysis to characterize both within-farm and farm-environment interactions. Flows were expressed on an annual basis according to the quantity of biomass exchanges multiplied by nitrogen content. Seventeen organic farms were surveyed in French grassland areas, each associating beef cattle with either sheep, pigs, or poultry. The ecological network analysis was then coupled with the assessment of farm economic, environmental, and social performances. A hierarchical clustering on principal components distinguished five groups of farms based on farm and herd size, presence of monogastrics, percentage of crops in the farm area, and system activity indicators. A large farm size, in terms of area or number of workers, can limit the implementation of a homogeneous flow network within the system. A higher level of within-system interactions did not lead to better farm economic, environmental, and social performances. Systems with large monogastric production enterprises were highly dependent on inputs, which led to less homogeneous flow networks and a poor farm nitrogen balance without gaining economic efficiency. Managing a complex system with a dense and complex flow network did not appear to increase farmers' mental workload. To our knowledge, this study is the first to quantify farm-scale interactions using ecological network indicators in temperate livestock farms and to analyze the links between farm performance and operating processes. The ecological network analysis thus potentially provides a common framework for comparing a wide range of livestock farms. Given the variability of multispecies livestock farms, a larger database will be used to extend our conclusions.
\end{abstract}

Keywords Organic farming $\cdot$ Indicators $\cdot$ Beef cattle $\cdot$ Sheep $\cdot$ Poultry $\cdot$ Pig $\cdot$ Efficiency

\section{Introduction}

Agricultural production systems have become highly specialized, resulting in the intensive use of various production factors (labor, inputs, and capital) and generating direct and indirect negative impacts on the environment. A broad consensus has been reached on the need to move away from the most heavily industrial forms of livestock farming and toward more sustainable models. These models would provide fair and stable remuneration for farmers, preserve natural resources, and limit environmental losses to the atmosphere and hydrosphere

Lucille Steinmetz

lucille.steinmetz@inrae.fr

1 Université Clermont Auvergne, INRAE, VetAgro Sup, UMR Herbivores, 63122 Saint-Genès-Champanelle, France while meeting societal expectations in terms of human and animal welfare, health, and product quality (ten Napel et al. 2011). Diversified systems, which intentionally include functional agrobiodiversity, i.e., diversity of crops, pastures, and animals bred by farmers (Kremen et al. 2012), are highly valued in agroecology and organic farming (Kremen et al. 2012; Ponisio et al. 2015; Dumont et al. 2020). Diversified systems could indeed make farm components interact in time and space to benefit from synergies, to be less dependent on inputs, and to take advantage of ecosystem services (Hendrickson et al. 2008). For instance, co-grazing by sheep and cattle is assumed to increase resource-use efficiency through their complementary feeding habits (d'Alexis et al. 2014) and to reduce the sheep parasite burden (Marley et al. 2006), while combining crops and livestock reduces the dependence on external inputs by enhancing farm selfsufficiency for feed and using manure instead of mineral 
fertilizers. These interactions result from practices adopted by farmers and define how the system operates. Within diversified systems, farm operations and how they relate to farm performances have been well analyzed in integrated croplivestock systems (Bell and Moore 2012; Ryschawy et al. 2014), but not as much in multispecies livestock (MSL) systems, i.e., where two or more animal species are kept on the same farm simultaneously (Martin et al. 2020). In this study, we aim to fill this knowledge gap. In particular, we want to describe within-system interactions and system-environment interactions as a proxy of farm operations and link farm operations to the performance of MSL farms.

Our study is based on organic farms in French grassland areas. We focus on organic farming (OF) systems, as these systems are assumed to optimize natural processes to face the challenge of not using chemical inputs. Indeed, OF is characterized by a strong link to the soil and a ban on chemical inputs, according to European Council Regulation No 834/2007 (EU 2007). After presenting the study sample of mixed beef cattle farms associated with either sheep, pigs, or poultry (Fig. 1), we applied an ecological network analysis (ENA) to represent farm operations, as previously conducted by Stark et al. (2018) in tropical croplivestock systems. We then define farm clusters based on farm structural characteristics and ecological network indicators and compare farm technical efficiency, farm nitrogen $(\mathrm{N})$ balance, and farmer well-being among clusters. Our analysis of farm operations is thus coupled to a multicriteria assessment of farm performance based on the three pillars of sustainability - economy, environment, and society. This comparative farm-scale study is indeed the first to analyze processes operating in three types of MSL farms with the same method and then test how within-system diversity and interactions are linked to multiperformance. These ecological network and performance indicators will enable a survey of a number of multispecies farms in a reasonable amount of time, thus allowing us to analyze the range of farmers' adaptive strategies and farm resilience.

\section{Materials and methods}

\subsection{Farm sample and sampling scheme}

We sampled farms according to several criteria. First, eligible farms had two commercial livestock production enterprises, i.e., beef cattle associated with either meat sheep, pigs, or poultry. Second, the whole farm was managed according to OF principles and had completed the conventional-to-organic conversion period. Third, at least a half full-time equivalent (FTE) worker was managing the system to ensure that the farms sampled were viable enterprises.

Once these three criteria were met, we opted to sample grassland farms at different altitudes (in lowlands and uplands) with contrasting marketing strategies (direct sales, integrated supply chain, etc.) and with or without crops or onfarm processing (meat-cutting workshop, mill, etc.). Farms in the sample sometimes counted a third animal species (e.g., horses or backyard chickens), but not for economic purposes.

Farms were surveyed during the MixEnable project (https://projects.au.dk/coreorganiccofund/core-organiccofund-projects/mix-enable/). We consulted the administrative and advisory services of the Auvergne, Limousin, and Occitanie regions to obtain a list of farms meeting these criteria. Sixteen farmers agreed to be interviewed. An additional farm is the Salamix farmlet experiment (https:/www6.inrae.fr/experimentations-systeme/ Les-experimentations/Elevage/Mixte/Salamix), which is a

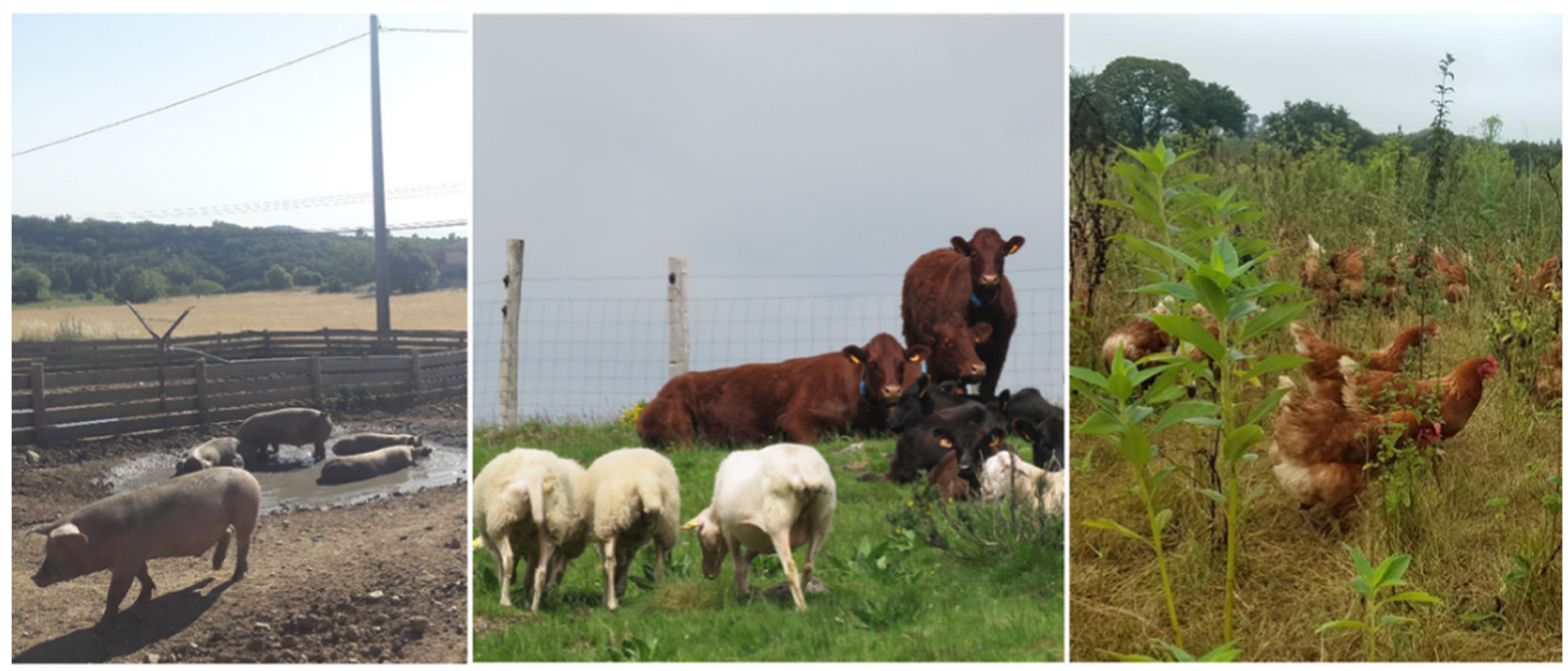

Fig. 1 Our farm surveys were conducted on three types of multispecies livestock farms, where beef cattle were associated with pigs, sheep, or poultry. Photo credits: Lucille Steinmetz, Eglantine Thiery and Solenn Brioude 
beef cattle-sheep grazing system managed by a half FTE worker at the INRAE Herbipôle research facility in Massif Central uplands $\left(45^{\circ} 39^{\prime} 02.9 \mathrm{~N} 2^{\circ} 44^{\prime} 01.0 \mathrm{E}\right)$.

In the final sample of 17 organic farms, beef cattle were associated with meat sheep $(n=7)$, pigs $(n=6)$, or poultry $(n=$ 4 ), with each species representing at least $10 \%$ of farm livestock units (LUs). Three farms with direct sales were below this species-ratio threshold but were retained to increase the diversity of the sampled MSL systems. The LU concept is widely employed in livestock farming system analyses to quantify the farm stocking density. It is based on the same shared unit among species and types of animal products but does not account for within-species variability in animal size and feeding requirements. Hence, for herbivores, we adjusted the LU coefficients according to cow and ewe metabolic weight to account for breed differences, as metabolic weight is the variable used to calculate maintenance requirements and additional requirements for production and draught power (IPCC 2019). We therefore multiplied the LU coefficient of each animal category by the ratio of the metabolic weight of the dam to the metabolic weight of a baseline dam counted as one animal unit (Smith et al. 2017). In France, one LU corresponds to a-600 kg liveweight dairy cow producing $3000 \mathrm{~kg}$ of milk and eating 3000 feed units (FU) per year (where $1 \mathrm{FU}$ is the energy content of $1 \mathrm{~kg}$ of barley; INRA 2018) or $4500 \mathrm{~kg}$ of dry matter for forages (Institut National de Gestion et d'Economie Rurale 1989). Based on this information and using an equivalence based on metabolic weight, a standard meat ewe weight of $52 \mathrm{~kg}$ corresponds to $0.15 \mathrm{LU}$. Monogastric LU coefficients were adapted based on energy and thus concentrate consumption in OF with the help of experts (Antoine Roinsard, ITAB, France and Marie Moerman, CRA-W, Belgium). We considered that an organic finishing pig consumes an average of $420 \mathrm{~kg}$ of concentrate ( $1 \mathrm{~kg}$ concentrate $=1 \mathrm{FU}$ ) regardless of the age at slaughter; therefore, we used a coefficient of $0.14 \mathrm{LU}(0.14=420 / 3000)$ for each pig sold. An organic sow consumes an average of $1500 \mathrm{~kg}$ of concentrate in 1 year, and all types of systems combined correspond to a coefficient of $0.5 \mathrm{LU}(0.5=$ 1500/3000). Replacement sows were counted for $0.14 \mathrm{LU}$ and piglets for $0.055 \mathrm{LU}$ (Cohen and Zahm 2011). Organic laying hens consume an average of $44.5 \mathrm{~kg}$ of concentrate per year, corresponding to $0.014 \mathrm{LU}(0.014=44.5 / 3000)$, while organic broilers consume an average of $6.2 \mathrm{~kg}$ of concentrates regardless of the length of the rearing period, which corresponds to $0.002 \mathrm{LU}(0.002=6.2 / 3000)$ for each broiler.

\subsection{Data collection}

The survey was built to obtain the data needed to obtain an overview of the farm structure, management, and performance in a reasonable time, i.e., no more than 3-4 $\mathrm{h}$ for the whole survey (a necessary condition for farmers to accept to receive us). It was composed of eight parts: farm structure (i.e., agricultural area and numbers of full-time and part-time workers), livestock, pastures, crops, sales, input purchased and use of byproducts, economics, and farmers' perceptions of their work. Each farmer was visited once for the 3-4-h interview, and many questions assessing quantitative or binary data were asked. Open-ended questions were also asked on practices related to grazing and pasture, effluent, and crop management. Farmers were also asked to provide (for later office analyses) the farm's accounts to calculate economic and quantitative indicators of sales and purchased inputs. Economic data were recorded for 2017, which is considered an average year in terms of climate and market conditions. Only 13 of the 16 commercial farmers agreed to share their farm's accounts; therefore, the economic assessment was not performed for three farms or for the INRAE farmlet experiment.

\subsection{Farm operating analysis integrating the ecological network analysis}

We used ENA, a holistic approach, to describe, quantify and analyze interactions among farm components. First developed for econometrics, Hannon (1973) applied this input-output analysis to ecology to describe the structure of the ecosystem and quantify within-system relationships. Rufino et al. (2009) applied a network analysis to "quantify the degree of integration and diversity of farm household systems using a set of indicators." Stark et al. subsequently proposed a new way of understanding and characterizing complex systems by considering the interactions between system components using indicators derived from ENA and used this method to analyze the benefits of crop-livestock integration in Latino-Caribbean farms (Stark et al. 2016, 2018). Here, we adapt this conceptual model to the case of MSL farms in temperate areas. Model implementation involved two stages: conceptualization and modeling.

The conceptualization stage consisted of defining system boundaries - in space and time - and components and identifying interactions among system components and between the system and its environment. Here, we worked at the farm level and adapted the segmentation of system components to fit the study objectives. Two animal components (beef cattle plus either meat sheep, pigs, or poultry) accounted for livestock, possibly with a third not-for-profit animal component being added to some farms. Annual grain crops and forage crops (such as corn silage or forage meslin) were aggregated into a single crop component. Grasslands were subdivided into two components, i.e., permanent (PG) or temporary (TG) grasslands, as each has its own management practices and a specific role in coupling carbon and $\mathrm{N}$ cycles. Consistent with Stark's model (Stark et al. 2016), we represented effluent and food storage as two distinct components. This distinction provided a link to the conceptual framework 
for levels of crop-livestock integration proposed by Bell and Moore (2012). We represented direct and indirect flows between components. For example, between grasslands and animals, direct flows occurred during grazing (grass intake and dejection) and were collocated interactions. Indirect flows relied on stored fodder or manure flows and were segregated interactions between animals and land. For example, animal dejections indoor were stored and then allocated to PG, TG, or crops according to farmer strategy. We split the fodder and grain storage sites to represent fodder flows from catch crops or cover crops separately from grain flows. In the present study, a cover crop was defined as a fast-growing crop that was grown between successive sowings of a main crop. It could be destroyed and left on the field, grazed by livestock or harvested for silage. One or more processing components, such as a meat-cutting plant or a mill, were added to some farms. Inputs corresponded to all the biomass entering the farm gate, i.e., feed, animals, organic fertilizers, seeds, and manure, whether purchased, received, or exchanged with neighbors. Input flows came from outside the system and arrived directly to the component where they were used. Outputs included sold, self-consumed, or exchanged farm products. Plant and effluent outflows left the system from their respective storage component, while animal outflow left the system from the animal component. On-farm processed products left the system from the processing component. Interactions corresponded to biomass flows between components or with the environment, and they reflected management practices such as feeding, harvesting, and manuring. The system runs over a production cycle of 1 year, and thus we assessed all the flows (purchases, sales, agricultural practices) and performances on this yearly basis.

Modeling consisted of selecting a unit and quantifying flows and storage changes. Flows were reported annually based on the quantity of biomass exchanged and multiplied by the $\mathrm{N}$ content (Table 1). We chose $\mathrm{N}$ as a common unit because $\mathrm{N}$ is an essential and mostly limiting nutrient in agriculture (Rufino et al. 2009). Moreover, $\mathrm{N}$ is viewed as a resource supporting production and as an environmental burden. Some biomass flows were not recorded on-farm and had to be estimated, such as grass intake and dung and urine excretions. Forage intake from cover crops or crop residues was estimated according to theoretical animal requirements of $4500 \mathrm{~kg}$ of dry matter per LU per year for the standard dairy cow (Institut National de Gestion et d'Economie Rurale 1989), number of grazing days, and herd size. Theoretical animal requirements were used, assuming that the needs of the animals were covered. Grass intake on pastures was estimated on a daily basis from animal requirements minus the consumption of hay and silage and estimated forage intake of cover crops and crop residues.

For animal components, the total amount of $\mathrm{N}$ excreted was calculated as the difference between $\mathrm{N}$ inputs (feed and animals purchased) and $\mathrm{N}$ outputs (sales or self-consumption). Effluent-related gaseous emissions were deducted from the $\mathrm{N}$ excreted to estimate the amount of $\mathrm{N}$ reaching the ground. These effluent-related gaseous emissions were calculated using the method reported by Gac et al. (2007), accounting for farming practices and the type of manure. Nitrogen that is not lost is assumed to be applied on pastures or crops. Plowing a TG makes $\mathrm{N}$ available for the next crop. The amount of $\mathrm{N}$ released after plowing grassland depends on the nature of the soil, age of the grassland, and grazing practice (Davies et al. 2001). However, as this accurate information was not available from the surveys, we worked with a fixed value of $100 \mathrm{~kg}$ N.ha ${ }^{-1}$ (Comifer 2013) that was multiplied by the average area of TG turned into cropland area each year. As grasslands were separated into TG and PG, we allocated forage production (grazed and harvested) to these two categories. This information was unable to be collected in the surveys, as the farmers were unable to provide a detailed grazing schedule. We thus proposed an approach that allocates fodder production to the TG and PG according to the management method. This approach required a series of assumptions: (1) a grassland that was only mowed was qualified as TG, as it was probably a pure legume or very productive grassland; (2) "harvested then grazed" grassland area was compared to the TG area. If the former was higher than the latter, then we considered that all TGs were "harvested then grazed," and some PGs were also managed in this manner to obtain the hectares of "harvested then grazed" grasslands. If the "harvested then grazed" grassland area was less than TG area, then the "harvested then grazed" grassland area was considered as TG; (3) a grassland that was only grazed was considered as non mechanizable and therefore as PG; and (4) wrapped-bale and grass silage were produced by mowing TG. These assumptions allowed us to calculate the relative share of hay, for example, area from TG and PG. Knowing the total quantity of forage (hay, silage, and wrapped) produced over the year and the distribution ratios between TG and PG enabled us to allocate the quantities of harvested forage to PG and TG components. We then calculated a "corrected fodder stocking rate," i.e., the number of herbivore LUs per fodder area (grassland + forage area) corrected by the number of LU equivalents fed with fodder from crops (intercropped and covered) and fodder purchased off-farm. This corrected fodder stocking rate allowed us to estimate a potential yield for grassland. We considered a similar potential yield for both TG and PG, as (i) PGs were productive mesophile grasslands and (ii) no additional information was provided by farmers. This potential yield enabled us to calculate the total potential production in tons of dry matter for each component. We then deducted the respective quantities of forage harvested to estimate the amount of grass potentially grazed in TG and PG.

$\mathrm{N}$ losses (run-off, leaching, and volatilization) largely depend on soil type, climate, and plot management. Accounting 
Table 1 Principal nitrogen coefficients used in the analysis

\begin{tabular}{|c|c|c|c|}
\hline Product & Nitrogen content & Unit & Source \\
\hline Cereals & 19 & $\operatorname{kg~N} . \mathrm{T} \mathrm{DM}^{-1}$ & INRA 2018 \\
\hline Mix cereal legumes & 21.5 & $\operatorname{kg~N} . \mathrm{T} \mathrm{DM}^{-1}$ & INRA 2018 \\
\hline Legume grain & 37.5 & $\operatorname{kg~N.~T~DM~}{ }^{-1}$ & INRA 2018 \\
\hline Crop residues & 15.2 & $\operatorname{kg~N} . \mathrm{T} \mathrm{DM}^{-1}$ & INRA 2018 \\
\hline Cover crop & 20.6 & kg N. T DM ${ }^{-1}$ & INRA 2018 \\
\hline Straw & 5.6 & kg N. T DM ${ }^{-1}$ & INRA 2018 \\
\hline PG grass & 22.4 & $\mathrm{~kg} \mathrm{~N}$. T DM ${ }^{-1}$ & INRA 2018 \\
\hline PG hay, bale, and silage & 17.6 & $\operatorname{kg~N} . \mathrm{T} \mathrm{DM}^{-1}$ & INRA 2018 \\
\hline TG grass & 25.6 & kg N. T DM ${ }^{-1}$ & Pelletier 2011 \\
\hline TG hay, bale, and silage & 21.3 & $\mathrm{~kg} \mathrm{~N} . \mathrm{T} \mathrm{DM}^{-1}$ & Pelletier 2011 \\
\hline Seed & 0.2 & $\operatorname{kg~N} . \mathrm{T} \mathrm{DM}^{-1}$ & Comifer 2013 \\
\hline Beef cattle & 25.28 & kg N. T LW ${ }^{-1}$ & Laisse et al. 2018 \\
\hline Meat sheep & 28.8 & kg N. T LW ${ }^{-1}$ & Laisse et al. 2018 \\
\hline Pig & 25.8 & kg N. T LW & Laisse et al. 2018 \\
\hline Broiler & 28.96 & $\operatorname{kg~N}$. T LW $^{-1}$ & Laisse et al. 2018 \\
\hline Hen & 16.48 & kg N. T LW' & Laisse et al. 2018 \\
\hline Egg & 19.2 & kg N. T FM"-1 & IDELE 1999 \\
\hline Powdered milk & 36 & kg N. T FM ${ }^{-1}$ & IDELE 1999 \\
\hline Beef cattle feed & 28.8 & kg N. T FM ${ }^{-1}$ & IDELE 1999 \\
\hline Meat sheep feed & 44.8 & kg N. T FM ${ }^{-1}$ & IDELE 1999 \\
\hline Pig feed & 27.2 & $\mathrm{~kg} \mathrm{~N} . \mathrm{T} \mathrm{FM}^{-1}$ & IDELE 1999 \\
\hline Broiler feed & 35.2 & kg N. T FM ${ }^{-1}$ & IDELE 1999 \\
\hline Hen feed & 26.4 & kg N. T FM ${ }^{-1}$ & IDELE 1999 \\
\hline Mixed cattle-sheep manure & 6.4 & $\mathrm{~kg} \mathrm{~N} . \mathrm{T} \mathrm{FM}^{-1}$ & $\begin{array}{l}\text { Personal calculation based } \\
\quad \text { on Comifer } 2013\end{array}$ \\
\hline Mixed cattle-pig manure & 6.9 & kg N. T FM ${ }^{-1}$ & $\begin{array}{l}\text { Personal calculation based } \\
\quad \text { on Comifer } 2013\end{array}$ \\
\hline Mixed cattle-poultry manure & 15.4 & kg N. T FM ${ }^{-1}$ & $\begin{array}{l}\text { Personal calculation based } \\
\quad \text { on Comifer } 2013\end{array}$ \\
\hline Mixed cattle-sheep compost & 6.7 & kg N. T FM ${ }^{-1}$ & $\begin{array}{l}\text { Personal calculation based } \\
\quad \text { on Comifer } 2013\end{array}$ \\
\hline Mixed cattle-pig compost & 6.5 & kg N. T FM ${ }^{-1}$ & $\begin{array}{l}\text { Personal calculation based } \\
\quad \text { on Comifer } 2013\end{array}$ \\
\hline Mixed cattle-poultry compost & 14.65 & kg N. T FM ${ }^{-1}$ & $\begin{array}{l}\text { Personal calculation based } \\
\text { on Comifer } 2013\end{array}$ \\
\hline
\end{tabular}

$D M$ dry matter, $L W$ liveweight, $F M$ fresh matter, $P G$ permanent grassland, $T G$ temporary grassland for these factors would require many approximations. For instance, the soil type cannot be precisely characterized, as some of the farms are located in areas where the soil type is not registered on national soil maps, while different soil types are also present on the same farm. We therefore did not quantify $\mathrm{N}$ losses at the farm level. $\mathrm{N}$ symbiotic fixation and $\mathrm{N}$ deposition were also not considered in the farm operation model to ensure a consistent input-output approach, as described in the studies by Rufino et al. (2009) and Stark et al. (2018). As some systems were not at equilibrium, inventory changes (end stockbeginning stock) were considered by adding positive changes to exports and negative changes to imports.

\subsection{Matrix construction and selected ENA indicators}

A matrix was then created with rows as the origin of $\mathrm{N}$ flows ( 0 to $n$ components) and columns as the destination of $\mathrm{N}$ flows (1 to $n+2$ components), where $n$ is the number of system components. The value of the flow reported in $\mathrm{kg}$ of $\mathrm{N}$ per hectare of usable agricultural area (UAA) per year is at the intersection. Row 0 corresponds to the inflows, i.e., imports (purchases). The last column corresponds to nonvaluable outflows, such as animal losses and gaseous emissions, and the penultimate column corresponds to valuable outflows sold, exchanged with neighbors, or self-consumed. 
Five network analysis indicators were calculated from this matrix, as described below. System activity corresponds to the total system throughflow (TST), which represents the sum of all flows circulating throughout the system, including both inflows and throughflows (Finn 1980; see Fig. 2). Total internal throughflow (TT) is the sum of all flows circulating among components, which represents the interaction activity. Link density (LD) is the ratio of the number of internal flows to the number of components (Latham 2006) and represents the internal flow density. The average mutual information (AMI) and the statistical uncertainty $(\mathrm{Hr})$ are used to assess the level of organization of the network of flows (Rutledge et al. 1976; Rufino et al. 2009; Stark et al. 2018). The AMI quantifies the organization of the flow network, where $\mathrm{Hr}$ is its upper bound. $\mathrm{Hr}$ illustrates the diversity of possible flows given the size of the system and the amount of throughput (T..), corresponding to the total quantity of $\mathrm{N}$ from all inflows, outflows, and flows within the system. If the total flow in a system is divided equally between all components and all components are connected, then AMI will be zero or very close to zero. Conversely, if the flow network is unbalanced with only a few main flows connecting few components, the AMI value will be close to its upper boundary (Hr). The AMI/Hr ratio is the proportion of diversity achieved based on the possible connections between system components (Rufino et al. 2009).

Both AMI and $\mathrm{Hr}$ consider the inflows and internal flows in their calculations. Here, we proposed a new indicator inspired by $\mathrm{AMI} / \mathrm{Hr}$ that only considered the internal flows to strictly assess internal flow organization (Eqs. 1 and 2). We defined the internal flow organization indicator as 1 $\mathrm{AMI} \mathrm{intern} / \mathrm{Hr}_{\text {intern }}$. The value of this indicator approaches 1 when flows are equally distributed among all components, indicating that the flow distribution is homogenous and approaches 0 when the flow distribution is heterogeneous. $T_{i j}$ is the value of the flow from component $i$ to component $j$, where $i$ is the number of rows and $j$ is the number of columns. $T_{i}$. is the total outflow for component $\mathrm{i}$, and $\mathrm{T}_{\mathrm{.j}}$ is the total inflow for component $\mathrm{j}$ :

$A M I_{\text {intern }}=\sum_{i=1}^{n} \sum_{j=1}^{n} \frac{T_{i j}}{T_{. .}} \log _{2} \frac{T_{i j} T_{. .}}{T_{i .} T_{. j}}$

$H r_{\text {intern }}=-\sum_{i=1}^{n} \frac{T_{i .}}{T_{. .}} \log _{2} \frac{T_{i .}}{T_{. .}}$

All flows were calculated using Excel to build a matrix. One file was created per farm. The indicators were calculated with R software using the enaR package (Lau et al. 2017). We adapted the calculation code for the organization indicator included in the $\mathrm{R}$ package to account only for internal flows and thus calculated the internal flow organization indicator.

\subsection{Farm structural indicators}

Farm operations mainly depend on farm structure factors, i.e., farm area, different workers, herd size, and composition. Moreover, the farm structure can influence indicator values (TT and TST), as farm size influences herd management and the technical efficiency of the production system (Veysset et al. 2015). The level of crop-livestock integration also affects farm performance (Ryschawy et al. 2012; Lemaire et al. 2014). We therefore included structural indicators in the analysis. We used UAA in hectares, the total number of workers in FTE and the total number of LUs to characterize the size of the farm. The percentage of crops (\%crops/ha), i.e., annual crops, including fodder crops, and the percentage of $\mathrm{PG}$ (\%permanent grassland/ha) within the UAA, provided additional information on the farm structure. The percentage of beef cattle LUs among total LUs (\%beef cattle/LU) on the
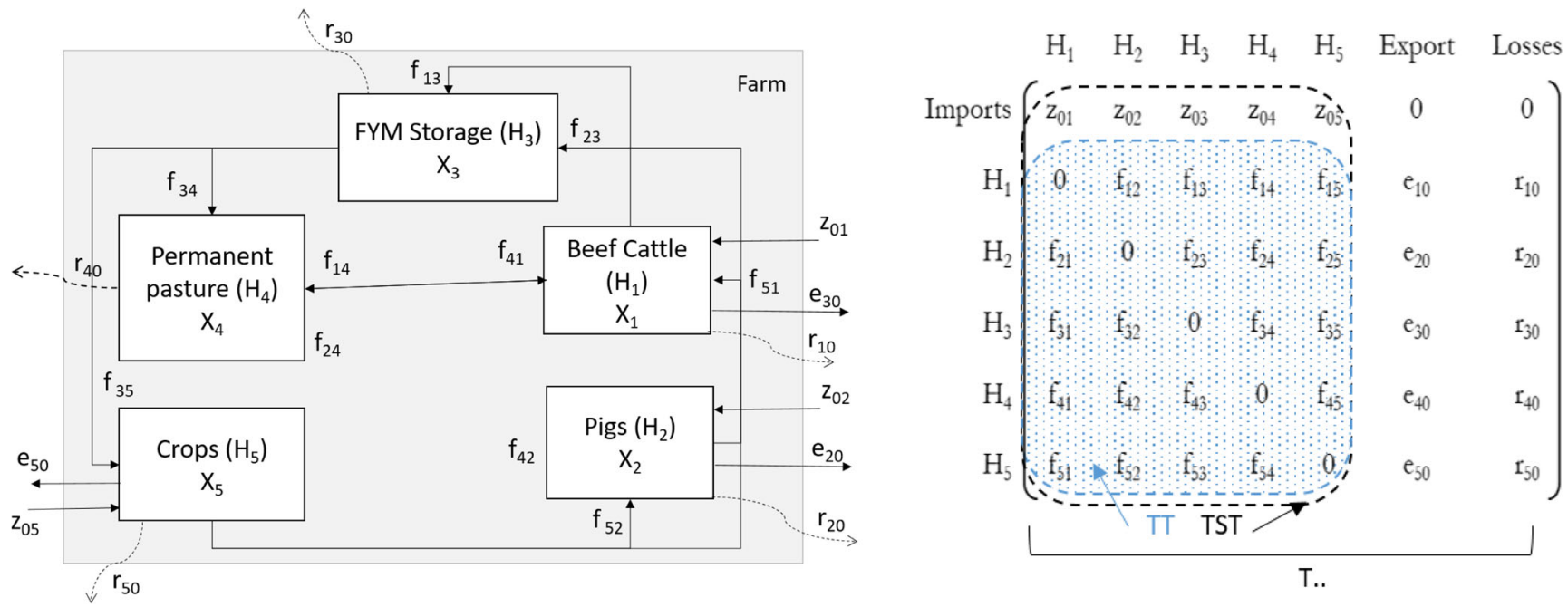

Fig. 2 Flow diagram and flow matrix. The blue dotted line indicates the flows used to calculate the internal flow organization. H1 is component 1; here, we have five components. X1 is the stock variation for component 1. e10 and r10 are export and loss flows, respectively 
farm provided information on the level of species mixing. The "fodder stocking rate," calculated using the method described in Section 2.3 without the correction, was used to evaluate the level of intensification of the fodder area. The "global stocking rate," defined as the total (monogastric and herbivore) number of LUs per hectare of UAA assessed the level of animal density at the farm level.

\subsection{Farm performance indicators}

We assessed the multiperformance of MSL farms by accounting for the three dimensions of sustainability. We retained three criteria: resource-use efficiency, environmental impact, and human well-being. The efficiency analysis highlights farms that are able to produce a large amount of output with little use of inputs or a moderate output with no inputs, thus defining low-input systems. Resource-use efficiency was assessed under $\mathrm{N}$, economic, and net protein efficiency (NPE) conditions. $\mathrm{N}$ efficiency, which was calculated from the ENA matrix, was defined as the ratio of $\mathrm{N}$ output to $\mathrm{N}$ input. Economic efficiency was defined as the ratio of added value to gross farm output (including subsidies in both variables). Added value corresponded to the gross farm output (sum of products sold and of stock variations minus purchased animals) minus intermediate consumption (i.e., the sum of goods and services purchased that are required to produce) and depreciation cost of equipment. Ruminants receive CAP subsidies that are essential to achieve profitability. We therefore integrated subsidies into the calculation of added value to compare the economic efficiency of different farm types. Economic efficiency was calculated from the farms' accountancy data. We also calculated farm NPE, i.e., the ratio of human-edible proteins contained in the food products to human-edible proteins in the feed consumed by the animals, using the corresponding human-edible protein content for each product proposed by Laisse et al. (2018). NPE facilitates an assessment of feed-food competition. A farm is a net producer of human-edible protein if it produces more food protein than it uses feed protein, i.e., if the ratio value of both variables reported in $\mathrm{kg}$ of edible protein is higher than one.

Environmental impact was assessed through $\mathrm{N}$ balances. We applied the Economic Input:Output (EIO) budget to calculate the $\mathrm{N}$ balance and the Biological Input:Output (BIO) budget to calculate the $\mathrm{N}$ balance with biological $\mathrm{N}$ fixation (BNF) (Watson and Atkinson 1999). Both parameters were calculated at the farm scale and accounted for $\mathrm{N}$ sales and $\mathrm{N}$ purchases over the farm gate. $\mathrm{N}$ sales corresponded to $\mathrm{N}$ outputs in the ENA matrix and $\mathrm{N}$ purchases to $\mathrm{N}$ inputs. In the $\mathrm{N}$ balance with BNF, the budget includes inputs from symbiotic $\mathrm{N}$ fixation and atmospheric $\mathrm{N}$ deposition, which enables the integration of the potential of legumes for closing the $\mathrm{N}$ cycle, which is especially important in OFs where chemical inputs are banned. BNF was calculated from the equation provided in the study by Anglade et al. (2015) applied to harvested yields, which includes belowground contributions such as $\mathrm{N}$ cycling associated with roots, nodules, and rhizodeposition. For the cereal legume mixture, the percentage of legumes in the crop was set to $20 \%$ (Vertès et al. 2015). For grasslands, we set a specific legume content for each type of grassland as follows: $13.3 \%$ for TG and $11 \%$ for PG (INRA 2018). The yield of a meadow, which was used to assess $\mathrm{N}$ export, corresponded to the sum of the grazed and harvested amount of grass. Field $\mathrm{N}$ deposition is a surfacedependent parameter. For this study, we used a single value of $10 \mathrm{~kg} \mathrm{~N} \mathrm{ha}^{-1}$ year $^{-1}$ (Dentener et al. 2006), which was multiplied by the UAA of each farm.

Farmer well-being at work was addressed by measuring three indicators: physical difficulty of work, mental workload, and overall satisfaction. The OECD also uses subjective indicators of well-being to analyze the impacts of their policies on the population (Boarini et al. 2012). Here, physical difficulty and mental workload were assessed because work is often considered more difficult physically in MSL systems due to the limited mechanization options (Martin et al. 2020). Labor is also quantitatively different from that in specialized systems with different types of knowledge, skills, and farmer capacities for monitoring system performance that can increase the mental workload (Kingwell 2011). In cattle-sheep systems, farmers also mentioned the pleasure of varied work and flexibility of the work organization as a matter of satisfaction (Mugnier et al. 2020). The assessment of these three indicators was based on farmers' perceptions, which is commonly used to evaluate farmer well-being (Besser and Mann 2015). During the surveys, farmers were asked three questions, one on each indicator, and farmers' perception indicators were scored on a 4-point scale, with a score of 1 indicating less satisfied and a score of 4 indicating most satisfied.

\subsection{Analysis of the indicators}

After performing univariate and bivariate analyses, a principal component analysis (PCA) was carried out on thirteen active variables (eight structural variables and five ENA variables) (Table 2) using R software and the FactoMineR package (Lê et al. 2008). Performance indicators were considered illustrative variables, and thus they were not included in the construction of principal components. We then conducted a hierarchical clustering on principal components (HCPC) analysis of the four first factors, again using the FactoMineR package. From the HCPC results, we calculated the ratio of intra inertia to total inertia, which illustrates the percentage of data variability in the HCPC analysis. We conducted a nonparametric test of multiple pairwise comparisons (Dunn) to determine whether the clusters performed identically in terms of the distributions and median values. The significance threshold was set to a $p$ value of $5 \%$. Each cluster was illustrated by its paragon 
(individual closest to the barycenter of the cluster) using the $\mathrm{R}$ package igraph (Ognyanova 2016) to represent the flows between system components and between components and the environment. The thickness of the arrow illustrates the intensity of the flow. The number of arrows according to the number of components illustrates the density of flow. Flow organization was defined as homogeneous when all the arrows had a similar thickness. When arrows of different thicknesses were observed, the flow organization was considered heterogeneous.

\section{Results and discussion}

\subsection{Farm structure similar to that of French livestock farms}

The average UAA for the 17 farms was 125.5 ha. Average values for the other size indicators were 103.1 LUs and 1.78 FTE. On average, $15.8 \%$ of farm UAA was cultivated (annual crops + fodder crops), 59.0\% was PG, and the remaining area corresponding to TG was included in crop rotations. The percentage of beef cattle in the farm herd ranged from 41 to $97 \%$ of LUs, with an average of $70.5 \%$ (Table 2). Four of the 17 farms had no crops and were considered pure grassland farms (Table 2). In the absence of references on MSL systems, we compared the structure of these farms to the French national network FADN-France 2017 (https://agreste.agriculture. gouv.fr/agreste-web/disaron/RICA_METRO/detail/). The size of farms in our sample was comparable to the average for French commercial farms with livestock (cattle, sheep, or goat) and mixed crop-livestock farms: the weighted average size of the farms from FADN-France 2017 was 111 ha, 103 LUs, and 1.68 FTE. Our farm sample was thus not different from the average French farm structures.

\subsection{ENA charts the diversity of farm operations}

The interaction activity (TT) and system activity (TST) ranged from 135 to 345 and 145 to $586 \mathrm{~kg} \mathrm{~N} \mathrm{ha}^{-1} \mathrm{yr}^{-1}$, respectively. The range of variation was identical, regardless of the species associated with beef cattle (Table 2). These indicators are correlated with the global stocking rate (Spearman's correlation coefficient of 0.81 for TT and 0.83 for TST). More animals per hectare leads to more resources consumed and more effluents excreted, all of which increase the amount of internal and total $\mathrm{N}$ circulating through the system. The internal flow organization indicator $\left(1-\mathrm{AMI}_{\text {intern }} / \mathrm{Hr}_{\text {intern }}\right)$ ranged from 0.41 for the most heterogeneous network of flows to 0.66 in the most homogenous network. Cattle-sheep farms scored higher (average value of 0.62 ) than cattle-monogastric farms, where internal flow organization averaged 0.51 for cattle-pig and 0.52 for cattle-poultry farms. Rearing two herbivore species on the same farm thus results in a more balanced flow network because both species make use of fodder from grasslands and crop areas. This result also explains why higher values for the internal flow density (LD) were observed in cattle-sheep farms (average value of 2.73) than in the other species combinations (2.16 for cattle-pig farms and 2.15 for cattle-poultry farms). The range of variations in LD and internal flow organization reflects the diversity of management practices implemented on farms, such as grazing crop residues, making fodder out of cover crops, and feeding animals bran produced on farms. Co-grazing or grazing crop residues is more common in multispecies herbivore farms, but monogastrics also value these resources. For example, poultry systems with mobile houses moving over TG, PG or crop areas throughout the year will lead to direct plant-animal interactions and increase internal flow density. In our sample, variability in both the size and production (broilers or hens) of beef-poultry systems resulted in the highest variability of intensity and internal flow organization indicators: two farms ran a small laying hen operation for direct sale, a third one had a subcontracted broiler system, and the fourth had a small broiler operation for direct sale. This diversity among cattlepoultry farms results from the different orientations and feeding strategies for poultry, which enables farmers to intensify production without increasing the farm area. This finding shows the potential of ENA indicators to reveal the diversity of within-system and system-environment interactions in MSL farms and thus to analyze farm operations through the organization and density of flows.

\subsection{A typology highlighting five contrasting farming systems}

Principal component analysis of the 13 structural and ENA variables showed that the first plane explained $62.5 \%$ of the variability in our $17 \mathrm{MSL}$ farm sample. Figure 3a shows the projection of active variables on this plan. System activity and interaction activity were positively correlated and positively correlated with the fodder stocking rate and global stocking rate. System activity and interaction activity were slightly negatively correlated with farm structure, i.e., to UAA and total workers. UAA and total workers were correlated, with a Spearman $R_{S}$ of 0.79 . The internal flow organization was negatively correlated with the farm structure (Fig. 3a), especially with the number of workers, with a Spearman $R_{S}$ of 0.63 . It was also negatively correlated with the percentage of crops in the UAA (Spearman $\mathrm{R}_{\mathrm{S}}=-0.53$ ). The percentage of PG in UAA was as expected opposed to the percentage of crops. The percentage of crops was positively correlated with the number of system components. The LU indicator and internal flow density mainly characterized the third and fourth PCA dimensions, respectively, which accounted for 13.9 and $12.9 \%$ of the variability. System activity and interaction 
Table 2 Farm operating and structural indicators calculated for the seventeen farms studied

\begin{tabular}{|c|c|c|c|c|c|c|c|c|c|c|c|c|c|c|c|c|c|}
\hline Farm identification code & S1 & $\mathrm{S} 2$ & S3 & S4 & S5 & S6 & S7 & Po1 & Po2 & Po3 & Po4 & Pil & Pi2 & Pi3 & Pi4 & Pi5 & Pi6 \\
\hline \multicolumn{18}{|l|}{ Operation indicators } \\
\hline Number of components & 8 & 8 & 8 & 8 & 8 & 5 & 5 & 8 & 9 & 9 & 6 & 8 & 9 & 8 & 8 & 6 & 8 \\
\hline Interaction activity $^{\mathrm{a}}$ (TT) & 247 & 175 & 135 & 227 & 266 & 177 & 205 & 345 & 214 & 142 & 245 & 136 & 174 & 328 & 233 & 138 & 161 \\
\hline System activity $^{\mathrm{a}}$ (TST) & 268 & 184 & 149 & 232 & 266 & 201 & 217 & 586 & 221 & 144 & 271 & 164 & 176 & 420 & 262 & 149 & 175 \\
\hline Internal flow organization ${ }^{\mathrm{b}}$ & 0.66 & 0.57 & 0.60 & 0.63 & 0.64 & 0.65 & 0.61 & 0.55 & 0.41 & 0.55 & 0.58 & 0.51 & 0.56 & 0.49 & 0.49 & 0.57 & 0.45 \\
\hline Internal flow density ${ }^{\mathrm{b}}$ (LD) & 3.4 & 2.9 & 2.9 & 3.1 & 2.9 & 2.0 & 2.0 & 2.4 & 2.1 & 2.4 & 1.7 & 2.4 & 2.4 & 2.3 & 2.4 & 1.7 & 1.9 \\
\hline \multicolumn{18}{|l|}{ Structure indicators } \\
\hline Usable agricultural area (ha) & 75 & 116 & 198 & 117 & 107 & 40 & 30 & 94 & 300 & 135 & 34 & 330 & 119 & 121 & 77 & 195 & 46 \\
\hline Permanent grassland (\% UAA) & 47 & 58 & 59 & 55 & 44 & 100 & 100 & 51 & 44 & 48 & 67 & 76 & 53 & 33 & 22 & 100 & 46 \\
\hline Crops (\% UAA) & 20 & 7 & 15 & 10 & 19 & 0 & 0 & 12 & 45 & 11 & 0 & 3 & 27 & 25 & 30 & 0 & 43 \\
\hline Livestock (LU) & 73 & 78 & 94 & 109 & 108 & 32 & 28 & 144 & 156 & 80 & 40 & 270 & 71 & 218 & 82 & 134 & 36 \\
\hline Beef cattle (\% LU) & 41 & 51 & 57 & 78 & 81 & 57 & 27 & 58 & 96 & 92 & 97 & 59 & 94 & 59 & 84 & 85 & 78 \\
\hline Total workers (FTE) & 1.0 & 1.3 & 2.3 & 1.0 & 1.5 & 0.5 & 1.0 & 1.0 & 4.0 & 2.2 & 1.2 & 3.0 & 2.6 & 1.9 & 1.3 & 2.5 & 2.0 \\
\hline Fodder stocking rate ${ }^{c}$ & 1.2 & 0.7 & 0.6 & 1.0 & 1.2 & 0.8 & 0.9 & 1.0 & 0.9 & 0.6 & 1.2 & 0.5 & 0.8 & 1.3 & 1.2 & 0.6 & 1.1 \\
\hline Global stocking rate $^{\mathrm{d}}$ & 1.0 & 0.7 & 0.5 & 0.9 & 1.0 & 0.8 & 0.9 & 1.5 & 0.5 & 0.6 & 1.2 & 0.8 & 0.6 & 1.8 & 1.1 & 0.7 & 0.8 \\
\hline
\end{tabular}

TT total internal throughflow, TST total system throughflow, $L D$ link density. ${ }^{\mathrm{a}}$ Kilograms of nitrogen per hectare per year; ${ }^{\mathrm{b}}$ unitless; ${ }^{\mathrm{c}}$ number of herbivore LUs per hectare of fodder area; ${ }^{\mathrm{d}}$ total (monogastric + herbivore) number of LUs per hectare of UAA. UAA usable agricultural area, $h a$ hectares, $L U$ livestock unit, FTE full time equivalent, $S$ sheep, $P i$ pig, Po poultry

activity were not correlated with the internal flow organization. This finding suggests that the homogeneity of the flow network is not linked to the amount of $\mathrm{N}$ circulating within it.

An HCPC analysis based on the four main factor components distinguished five groups of farms based on the UAA, LU, farming system, and farm activity (Fig. 3b). The ratio of internal inertia to total inertia associated with the partition into five classes was $65 \%$, indicating that this typology accounts for approximately two-thirds of the data variability. Each cluster was graphically represented by its paragon (Fig. 4). Clusters did not necessarily group farms with the same combination of animal species, i.e., cattle with either sheep, pigs, or poultry. Thus, the two animal species of the paragon were not representative of the species combination found in all the farms of the cluster. Cluster 1 included large-UAA farms with a low animal density (global stocking rate), as illustrated by the thin arrows between cattle and grassland (Fig. 4 (1)) and was therefore qualified as "large extensive land-related farms." Cluster 2 was characterized by a high number of components, a high percentage of crops in the UAA, and a dominance of cattle in the farm herd, as evidenced by a predominance of cattle-connected flows (Fig. 4 (2)) and a heterogeneous flow organization. Cluster 2 was qualified as "mixed crop-livestock farms with beef cattle and a small monogastric enterprise." In contrast, cluster 3 was characterized by a homogeneous flow organization and a high internal flow density. It only included relatively species-balanced beef cattlesheep farms. Figure 4 (3) clearly illustrates the ability of cattle and sheep to graze and exploit stored fodder. Cluster 3 was named "beef cattle-sheep farms in mixed crop-livestock systems." Cluster 4 was characterized by small-UAA and lowLU farms with a high percentage of PG in the UAA. Despite the limited number of components, components were well interconnected, and arrows had similar thicknesses, which explained the high value for the flow organization for this cluster. Cluster 4 was qualified as "small grassland farms" compared to the average size of the whole sample. Cluster 5 grouped two beef cattle-monogastric farms characterized by a high interaction and system activity due to the high livestock density and high reliance on inputs, as illustrated by thicker arrows within and entering the system compared to other clusters. Cluster 5 was qualified as an "intensive beef cattlemonogastric farms." Notably, the four cattle-poultry farms were distributed among three clusters as a result of the diverse orientation and animal intensification of these farms.

In our farm sample, within-system interactions appeared to be limited by large farm areas associated with a large number of workers. We assume that a large farm area will lead to a simplification of management practices, which was, for instance, observed in the research-development project RED SPyCe, where a total of 673 mixed crop-livestock and grassland farms were sampled across France. The authors used several structure and management practice indicators proposed by Martel et al. (2017) to evaluate the strength of crop-livestock interactions. They showed that larger farms were less integrated than smaller farms (Mischler et al. 
a

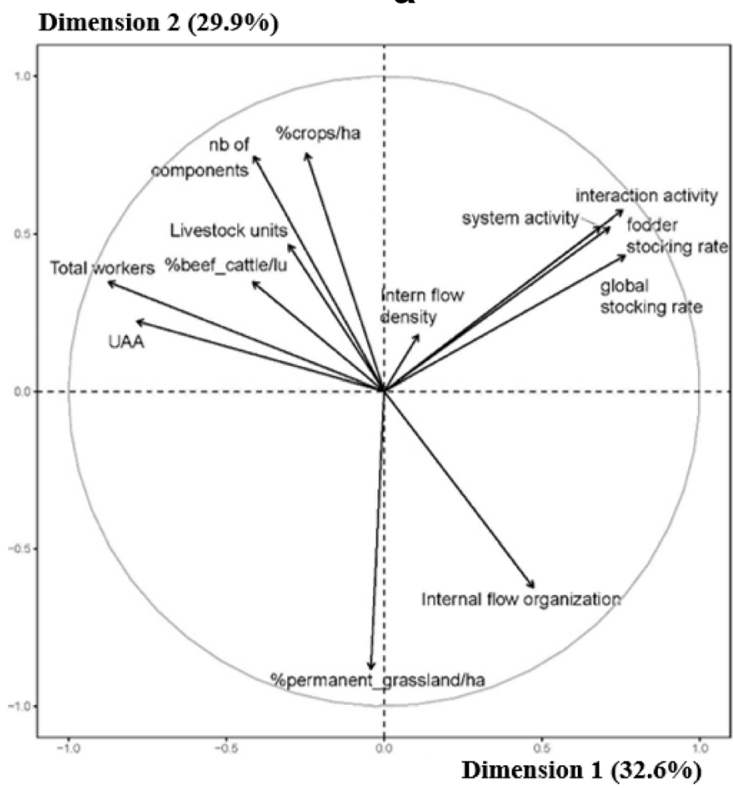

Fig. 3 Principal component analysis of the 17 farms studied according to operation and structure indicators followed by a hierarchical clustering of principal components analysis. Graph a represents the distribution of active variables along the first two components. Graph $\mathbf{b}$ represents the

\section{Dimension 2 (29.9\%)}

\section{b}

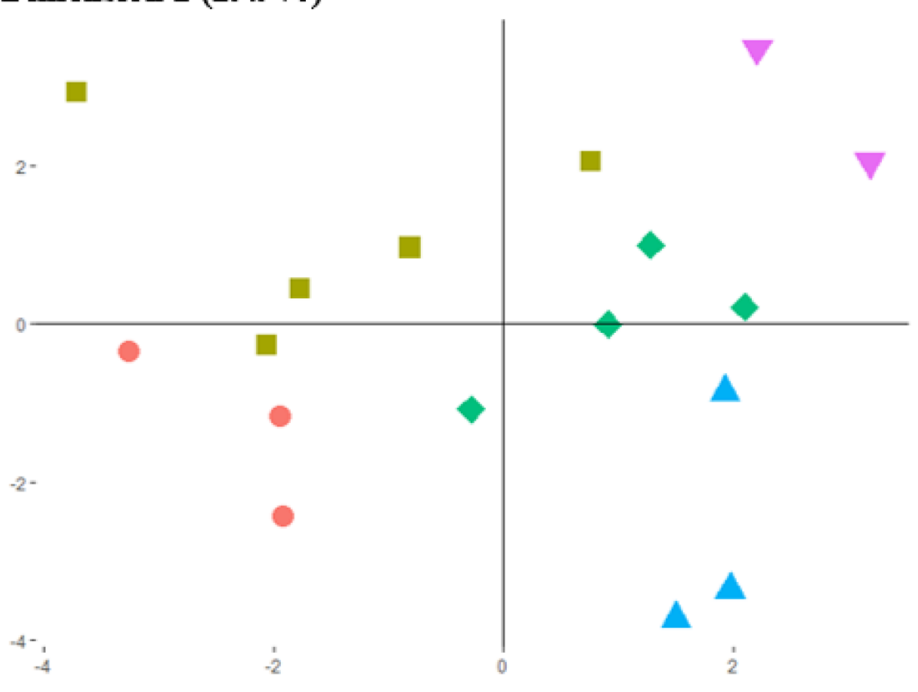

Dimension 1 (32.6\%)

distribution of the farms studied along the first two components. Colors and shapes illustrate the results of the clustering analysis. Red circles: farms from cluster 1. Green-yellow squares: cluster 2. Green diamonds: cluster 3. Blue triangles: cluster 4. Purple inverted triangles: cluster 5
2018). Considering the negative correlation between internal flow organization and the size of the worker collective, one may wonder if a threshold effect exists at which the size of the collective becomes a limiting factor. This negative correlation might result from the small sample size and MSL diversity rather than from a direct effect of the number of workers on internal flow organization. Meanwhile, increasing the number of workers also increases coordination costs, whereas a low number of workers does not enable fine monitoring of the system and could lead to stagnation.

We show that ENA can represent different ruminant and/or monogastric systems with or without crops within the same conceptual framework. This approach allows us to generalize both the calculation of indicators and the representation of components and within-system interactions, helps understand the functioning of the system, and provides a synthetic vision. ENA was applied on temperate commercial farms for the first time, and the clustering results were consistent with the typology of European livestock farming systems (Dumont et al. 2019). Indeed, the farm structure (area, grassland vs mixed crop-livestock system), animal feeding intensification, and presence of monogastrics are factors with major effects on the system organization, according to our clustering analysis. These factors could be mobilized in future research when sampling farms to (i) select farms with a comparable structure and commercialization constraints/ opportunities to study differences in farm operation, (ii) select farms representing a wide range of structures and animal feeding intensification to identify a potential link between them, and (iii) select farms with the same animal combination with a gradient of proportions of each animal species.

\subsection{No link between performances and farm typology}

The five clusters did not differ significantly in terms of farm performance, according to the nonparametric test of multiple pairwise comparisons (Dunn). However, we did observe some interesting relationships.

Fig. 4 Network illustration for the paragon of each cluster. The size of animal components depends on the percentage of the total LUs represented by each of them. The size of plant-biomass components (crops, permanent and temporary pastures) depends on the percentage of the UAA represented by each of them. The size of the storage and transformation components is fixed. The upstream and downstream entities (inputs and outputs) are represented as components to chart inflows and outflows. The size of the input component represents the share of inflows in the sum of inflows and outflows. Thicker arrows illustrate a greater quantity of nitrogen in kilograms per hectare per year exchanged between components. Black arrows represent inflows and outflows, and gray arrows represent throughflows. Crops component gathers annuel grain crops and forage crops. Inputs corresponded to all the biomass entering the farm gate, i.e., feed, animals, organic fertilizers, seeds, and manure, Outputs included sold, self-consumed, or exchanged farm products. Transformation represents a processing component, such as a meat-cutting plant or a mill 

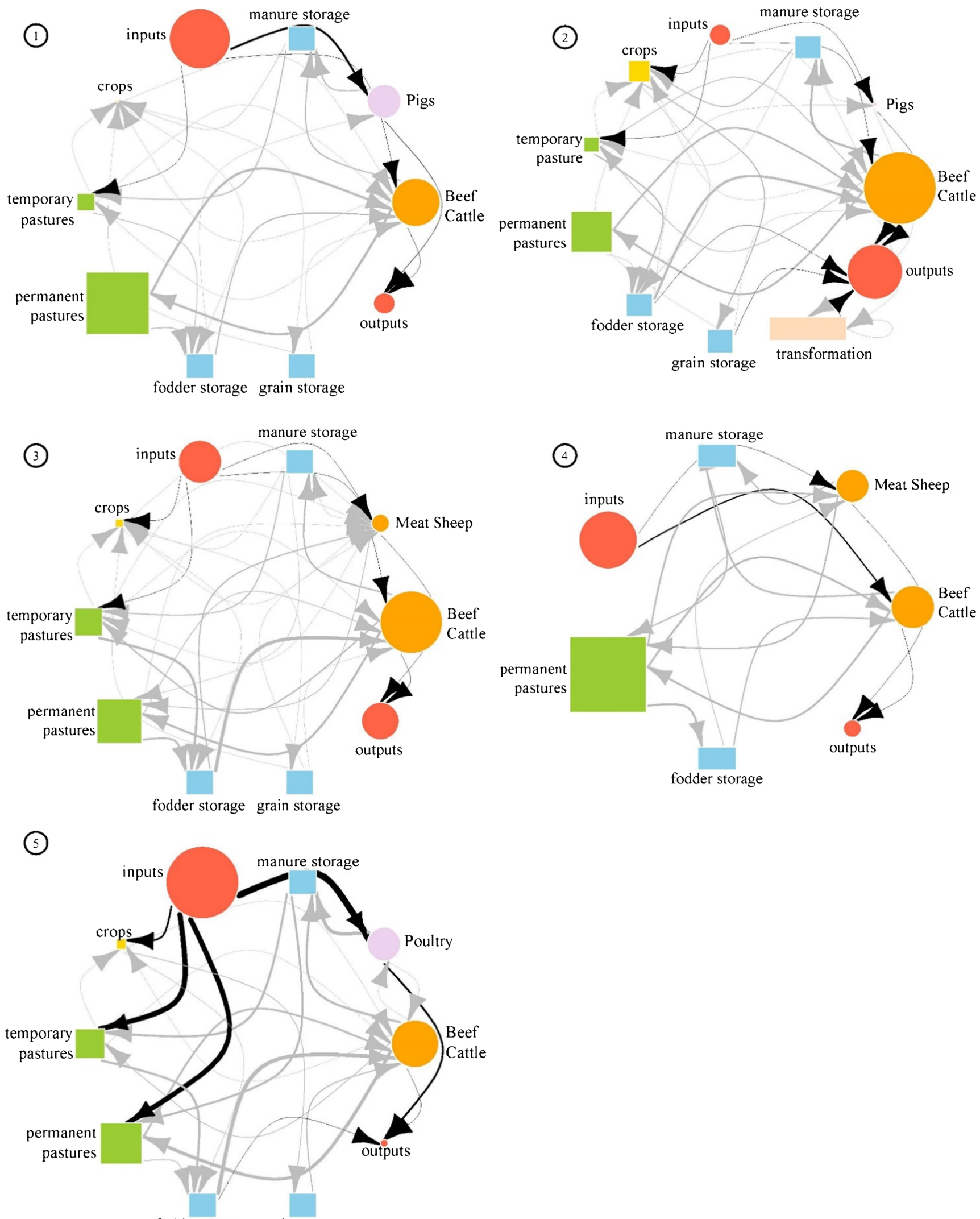

fodder storage grain storage 


\subsubsection{Nitrogen efficiency}

We addressed efficiency at three levels. For $\mathrm{N}$ use efficiency, our sample counted four efficient farms with a value greater than 1, mainly in cluster 2 (Table 3). Farms S5 and Po3 reached extreme values (328.94 and 15.33, respectively) due to their low feed and fertilizer purchases. Their only expenses were on seeds and chicks, respectively. This high $\mathrm{N}$ use efficiency was associated with a negative $\mathrm{N}$ balance. However, when considering symbiotic $\mathrm{N}$ fixation and atmospheric deposition, the $\mathrm{N}$ balance remained positive (Table 3 ), indicating that legumes play a major role in closing the $\mathrm{N}$ cycle and in the agronomic sustainability of the system. The two "intensive beef cattle-monogastric farms" of cluster 5, which were highly input-dependent, had very low $\mathrm{N}$ efficiency with high negative environmental impacts in terms of $\mathrm{N}$ surplus, as revealed by the high value for the $\mathrm{N}$ balance.

\subsubsection{Economic efficiency}

The economic efficiency of our sample was not very good overall. Substantial intracluster variability was observed (Fig. 5), but the two farms (Po2 and Pi2) with the best economic efficiency ( 0.45 and 0.50 , respectively), both in cluster 2 , were also the only ones to have an on-farm processing operation. This finding raises the question of whether processing products on farms guarantees a better economic efficiency. It is a method to increase added value on the farm. Farm S2 sold breeding animals that were better remunerated than fattened animals, which also allows it to have good economic efficiency (0.41). Our assessment of economic efficiency was based on the ratio of added value to gross product but added value also considers the intermediate costs and depreciation. Thus, financial and management choices, such as marketing decisions, selling prices, product diversity, and animal intensification, all have similar effects on economic performance to within-system interactions. Our observations were consistent with other findings in beef (Veysset et al. 2015) or dairy cattle (Perrot et al. 2013), where no consistent economic advantage was observed for mixed crop-livestock or grassland-based systems when analyzing only the benefits of interactions per se. Indeed, economic performance does not appear to be linked to specialization or diversification of farm activity but to farmers' choices in terms of input management and adaptation strategies (Dumont et al. 2020; Martin et al. 2020).

\subsubsection{Feed-food competition}

Feed-food competition was evaluated through NPE. Only one farm (Po2) was a net producer of human-edible protein (NPE $=1.7$ ) due to the presence of an important cash crop enterprise (45\% of UAA) on the farm. Indeed, crop products contain a higher proportion of human-edible protein and have a higher yield per hectare than animal products. For other systems, we observed a positive correlation between NPE and internal flow organization (Spearman $R_{S}=0.30$, with $R_{S}=0.9$ for beefpigs combination), suggesting that enhancing the use of farm resources by allowing farm enterprises to interact would allow a decrease in feed-food competition. This observation may be valid only if animals consume resources that are not edible by humans, i.e., grass or fodder. The beef cattle-sheep farm S6 had a neutral protein efficiency $(\mathrm{NPE}=1)$, i.e., the farm produced as much human-edible protein as it consumed. Farm S6 is the INRAE farmlet experiment based on good animal

Table 3 Farm performance indicators presented by cluster for the seventeen farms studied

\begin{tabular}{|c|c|c|c|c|c|c|c|c|c|c|c|c|c|c|c|c|c|}
\hline \multirow{2}{*}{$\begin{array}{l}\text { Cluster } \\
\text { Farm }\end{array}$} & \multicolumn{3}{|c|}{1} & \multicolumn{5}{|c|}{2} & \multicolumn{4}{|c|}{3} & \multicolumn{3}{|c|}{4} & \multicolumn{2}{|c|}{5} \\
\hline & $\mathrm{S} 3$ & Pi1 & Pi5 & Po2 & Po3 & Pi2 & Pi4 & Pi6 & $\mathrm{S} 1$ & S2 & S4 & S5 & S6 & S7 & Po4 & Po1 & Pi3 \\
\hline \multicolumn{18}{|l|}{ Efficiency } \\
\hline $\mathrm{N}$ efficiency & 0.76 & 0.35 & 0.39 & 3.32 & 15.33 & 2.55 & 0.18 & 0.79 & 0.31 & 0.66 & 0.86 & 329 & 0.31 & 0.29 & 0.25 & 0.11 & 0.29 \\
\hline Economic efficiency & 0.07 & 0.19 & 0.23 & 0.45 & 0.38 & 0.50 & 0.24 & 0.09 & 0.32 & 0.41 & 0.20 & NA & NA & NA & NA & 0.21 & 0.24 \\
\hline Net protein efficiency & 0.70 & 0.66 & 0.66 & 1.72 & 0.82 & 0.83 & 0.29 & 0.26 & 0.43 & 0.63 & 0.91 & 0.34 & 0.99 & 0.34 & 0.55 & 0.39 & 0.55 \\
\hline \multicolumn{18}{|l|}{ Environmental impact } \\
\hline $\mathrm{N}$ balance & 3 & 17 & 7 & -17 & -12 & -5 & 21 & 3 & 14 & 3 & 1 & -6 & 16 & 9 & 19 & 214 & 64 \\
\hline $\mathrm{N}$ balance with BNF & 75 & 97 & 90 & 91 & 79 & 83 & 177 & 82 & 128 & 109 & 119 & 149 & 128 & 131 & 173 & 358 & 203 \\
\hline \multicolumn{18}{|l|}{ Social indicators } \\
\hline Physical difficulty & NA & 3 & 2 & 2 & 2 & 2 & 3 & 2 & 3 & 3 & 3 & 2 & NA & 2 & 2 & 2 & 2 \\
\hline Mental workload & NA & 1 & 3 & 1 & 2 & 2 & 2 & 3 & 2 & 2 & 2 & 3 & NA & 1 & 2 & 1 & 2 \\
\hline Overall satisfaction & NA & 4 & 4 & 3 & 3 & 3 & 3 & 3 & 4 & 3 & 4 & 3 & NA & 4 & 3 & 3 & 3 \\
\hline
\end{tabular}

Efficiency indicators are unitless. Environmental indicators are reported in kilograms of nitrogen per hectare per year. Social indicators have values from $1(-)$ to 4(+). $S$ sheep, $P i$ pig, Po poultry, $N A$ no data available, $N$ nitrogen, $B N F$ biological nitrogen fixation 
Physical difficulty

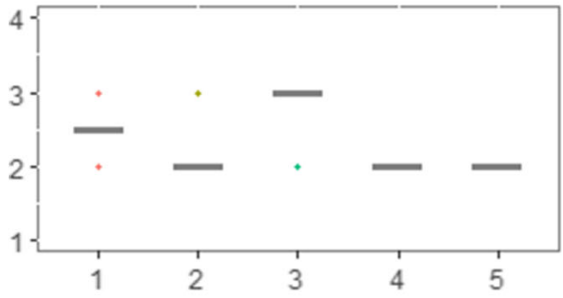

Nitrogen efficiency

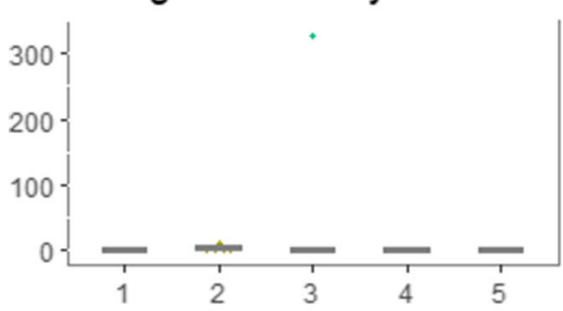

Farm nitrogen balance

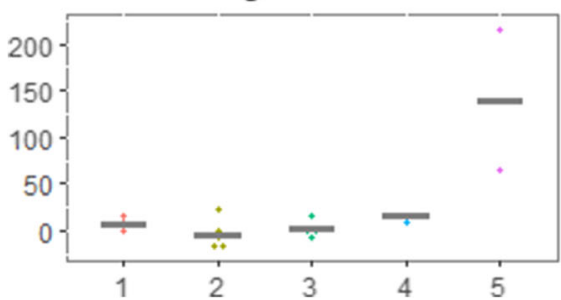

Fig. 5 Boxplots for eight performance indicators. The $x$-axis represents the five clusters. Arduousness, complexity, and overall satisfaction are rated from a score of 1 indicating least satisfied to a score of 4 indicating most satisfied. Farm nitrogen balance and farm nitrogen balance with
Mental load

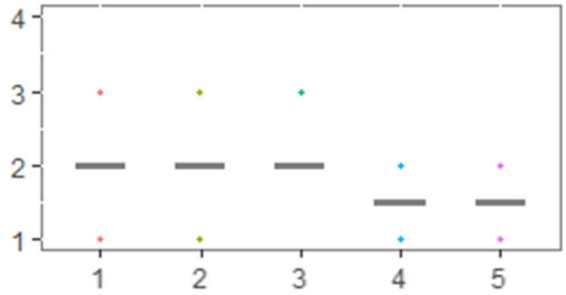

Economic efficiency

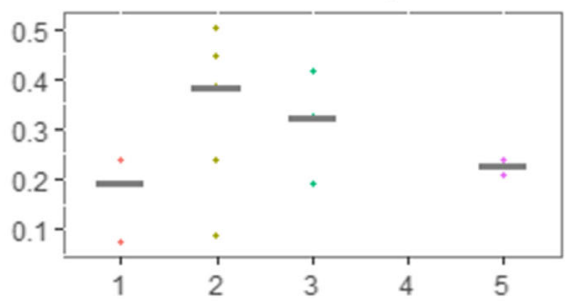

Farm nitrogen balance with BNF

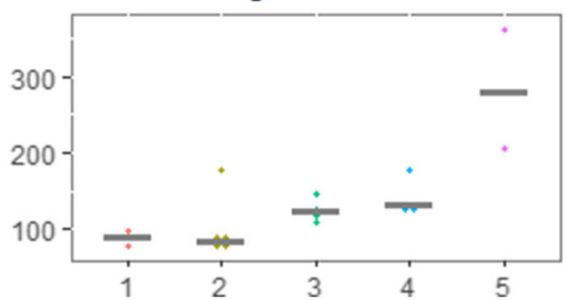

Overall satisfaction

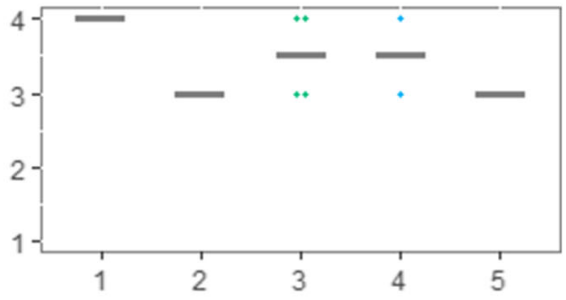

Net protein efficiency

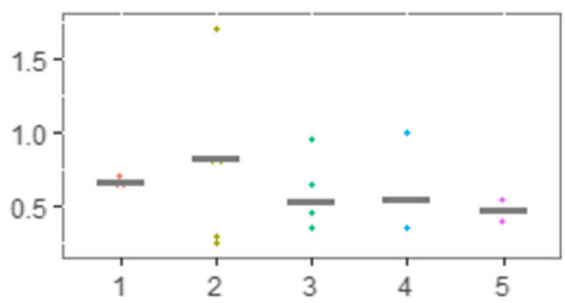

BNF (biological nitrogen fixation) are presented in kilograms of nitrogen per hectare per year. The three efficiency indicators are unitless. A gray crossbar represents the median of each cluster

productivity and optimized grass utilization. This result extents the study by Laisse et al. (2018), who showed that some self-sufficient, grassland-based dairy, or sheep-meat systems can produce more protein than they consume.

\subsubsection{Human well-being}

Human well-being was assessed by farmers' perceptions of their work conditions: physical difficulty, mental workload, and overall satisfaction. We observed no effects of the farm structure and operation on human well-being (Table 3), while farmers in cluster 3 of beef cattle-sheep farms with many within-system interactions did not find their system more complex to manage than other farmers (Fig. 5). For example, farmer S5, who managed one of the most homogeneous flow network (internal flow organization $=0.64$, Table 2 ), assessed his work as usually easy to manage (mental workload $=3$, Table 3). We assume that the farmer is well organized and not overwhelmed by the diversity of tasks to be completed or that management complexity is viewed as a strength to keep from getting bored and not as a load (Salmona 1994; Mugnier et al. 2020). These preliminary results on human well-being were based on farmers' self-assessments, which may be influenced by the conditions and farmer's state of mind at the time of the interview (Conceição and Bandura 2008). This approach could be combined with other methods relying on a longer immersion in the routine of farm life, focusing on farmers with contrasted adaptive strategies. Systemic studies still underaccount for the human factor in the system. However, the socioecological and economic contexts have an impact on organic farmers through the management and orientation of his/her system (Bouttes et al. 2019). For example, Nkurunziza et al. (2020) have shown that the performance of barley production in organic farming is determined by socioecological factors, whereas in conventional agriculture, it mainly depends on mineral fertilizer. We therefore must apply transdisciplinarity, notably associating technicaleconomic and sociological approaches, to understand the choices made by organic mixed breeders.

\section{Conclusions and perspectives}

The scientific literature identifies diversified livestock farming systems as promising options in terms of meeting environmental and societal demands, but the issue is not "cut-and-dry," and 
clearly scope exists to further explore the topic. The ENA is a generic approach for calculating indicators and representing farm operations across a range of production systems. Here, the ENA enabled us to compare MSL farms on a common basis and to represent the strengths and directions of interactions among farm components. However, our farm sample accounting for three types of animal species combinations is too small to statistically link farm operations and farm multiperformance. This first series of surveys facilitated the identification of key structural variables, such as farm size, grassland-crop balance, and size of the monogastric enterprise, that strongly drive the network structure and thus must be considered in a forthcoming sampling strategy. A wider farm sample should also account for the range of sales of processed products and for direct selling that strongly impact farm economic efficiency. This wider farm sample structured by these key variables would allow us to support solidly powered statistical analyses to identify the factors influencing performance in MSL farms. Then, the challenge is compounded by the complexity of defining what would be the adequate number of interactions among the most ideal potential benefits and timing of interactions. A sufficiently dense network of interactions is needed to provide adaptation levers, but the right choice also depends on the presence of alternative interactions that could be mobilized to adapt to any condition of a fluctuating environment. For instance, crop residues are viewed as an alternative resource to temporarily decrease the fodder stocking rate and provide flexibility to face climatic hazards. Finally, although we proposed indicators based on the three dimensions of sustainability, the surveys mainly provide information on the technico-economic dimension. Our focus on a small number of performance indicators is thus a limitation, but we successfully included key environmental and societal dimensions within a reasonable time for conducting the survey and provided an analytical method to link the interaction network to farm multiperformance. This link is highly valued in agroecology and OF. A reasonable survey time would allow farmers involved in the agroecological transition to be monitored over time in order to understand their adaptive strategies and analyze farm resilience.

Acknowledgements The authors thank all the farmers who cooperatively agreed to answer our questions, C. Troquier who participated in farm surveys, F. Stark for his advice on the ENA methodology, and G. Martin for coordinating the MIX-ENABLE project. The authors also thank the two reviewers for their insightful comments, which allowed us to improve the manuscript.

Authors' contributions Conceptualization: LS, PV, MB, and BD; software: LS; methodology: LS, PV, MB and BD; Formal analysis: LS; Visualization: LS; Writing-original draft: LS; and Writing-review and editing: LS, PV, MB and BD.

Funding This study was supported by the financial support for the MIXENABLE project provided by transnational funding bodies, namely, partners of the H2020 ERA net project, CORE Organic Cofund, and the cofund from the European Commission. L. Steinmetz is supported by the French government IDEX-ISITE initiative 16-IDEX-0001 (CAP 2025).

Data availability The datasets generated and/or analyzed during the current study are available from the authors upon reasonable request.

Code availability Not applicable

\section{Declaration}

Ethics approval Not applicable

Consent to participate Verbal informed consent was obtained from farmers prior to the interviews.

Consent for publication Verbal informed consent was obtained from farmers to publish their data anonymously.

Conflict of interest The authors declare no competing interests.

Open Access This article is licensed under a Creative Commons Attribution 4.0 International License, which permits use, sharing, adaptation, distribution and reproduction in any medium or format, as long as you give appropriate credit to the original author(s) and the source, provide a link to the Creative Commons licence, and indicate if changes were made. The images or other third party material in this article are included in the article's Creative Commons licence, unless indicated otherwise in a credit line to the material. If material is not included in the article's Creative Commons licence and your intended use is not permitted by statutory regulation or exceeds the permitted use, you will need to obtain permission directly from the copyright holder. To view a copy of this licence, visit http://creativecommons.org/licenses/by/4.0/.

\section{References}

Anglade J, Billen G, Garnier J (2015) Relationships for estimating N2 fixation in legumes: incidence for $\mathrm{N}$ balance of legume-based cropping systems in Europe. Ecosphere 6:37. https://doi.org/10. 1890/ES14-00353.1

Bell LW, Moore AD (2012) Integrated crop-livestock systems in Australian agriculture: trends, drivers and implications. Agric Syst 111:1-12. https://doi.org/10.1016/j.agsy.2012.04.003

Besser T, Mann S (2015) Which farm characteristics influence work satisfaction? An analysis of two agricultural systems. Agric Syst 141:107-112. https://doi.org/10.1016/j.agsy.2015.10.003

Boarini R, Comola M, Smith C et al (2012) What makes for a better life?: the determinants of subjective well-being in OECD countries - evidence from the Gallup World Poll. OECD Publishing

Bouttes M, Darnhofer I, Martin G (2019) Converting to organic farming as a way to enhance adaptive capacity. Org Agric 9:235-247. https://doi.org/10.1007/s13165-018-0225-y

Cohen S, Zahm F (2011) IDEA: Outils d'application. Calcul des UGB A10-. In: Indicateurs de Durabilité des Exploitation Agricoles. https://idea.chlorofil.fr/utilisation/outils-dapplication.html. Accessed 14 Mar 2020

Comifer (2013) Calcul de la fertilisation azotée - Guide méthodologique pour l'établissement des prescriptions locales, Comifer. Comifer, Paris

Conceição P, Bandura R (2008) Measuring subjective wellbeing: a summary review of the literature. United Nations Dev Program 1-35 
d'Alexis S, Sauvant D, Boval M (2014) Mixed grazing systems of sheep and cattle to improve liveweight gain: a quantitative review. J Agric Sci 152:655-666. https://doi.org/10.1017/S0021859613000622

Davies M, Smith K, Vinten A (2001) The mineralisation and fate of nitrogen following ploughing of grass and grass-clover swards. Biol Fertil Soils 33:423-434. https://doi.org/10.1007/ s003740100348

Dentener F, Drevet J, Lamarque JF, Bey I, Eickhout B, Fiore AM, Hauglustaine D, Horowitz LW, Krol M, Kulshrestha UC, Lawrence M, Galy-Lacaux C, Rast S, Shindell D, Stevenson D, van Noije T, Atherton C, Bell N, Bergman D, Butler T, Cofala J, Collins B, Doherty R, Ellingsen K, Galloway J, Gauss M, Montanaro V, Müller JF, Pitari G, Rodriguez J, Sanderson M, Solmon F, Strahan S, Schultz M, Sudo K, Szopa S, Wild O (2006) Nitrogen and sulfur deposition on regional and global scales: a multimodel evaluation. Global Biogeochem Cycles 20:21. https:// doi.org/10.1029/2005GB002672

Dumont B, Puillet L, Martin G, Savietto D, Aubin J, Ingrand S, Niderkorn V, Steinmetz L, Thomas M (2020) Incorporating diversity into animal production systems can increase their performance and strengthen their resilience. Front Sustain Food Syst 4:109. https://doi.org/10.3389/fsufs.2020.00109

Dumont B, Ryschawy J, Duru M, Benoit M, Chatellier V, Delaby L, Donnars C, Dupraz P, Lemauviel-Lavenant S, Méda B, Vollet D, Sabatier R (2019) Review: associations among goods, impacts and ecosystem services provided by livestock farming. Animal 13: 1773-1784. https://doi.org/10.1017/S1751731118002586

EU (2007) Council Regulation (EC) No 834/2007 of 28 June 2007 on organic production and labelling of organic products and repealing Regulation (EEC) No 2092/91

Finn JT (1980) Flow analysis of models of the Hubbard Brook ecosystem. Ecology 61:562-571. https://doi.org/10.2307/1937422

Gac A, Béline F, Bioteau T, Maguet K (2007) A French inventory of gaseous emissions $(\mathrm{CH} 4, \mathrm{~N} 2 \mathrm{O}, \mathrm{NH} 3)$ from livestock manure management using a mass-flow approach. Livest Sci 112:252-260. https://doi.org/10.1016/j.livsci.2007.09.006

Hannon B (1973) The structure of ecosystems. J Theor Biol 41:535-546. https://doi.org/10.1016/0022-5193(73)90060-X

Hendrickson JR, Hanson JD, Tanaka DL, Sassenrath G (2008) Principles of integrated agricultural systems: introduction to processes and definition. Renew Agric Food Syst 23:265-271. https://doi.org/10. 1017/S1742170507001718

IDELE (1999) Le bilan des minéraux - le cahier de l'éleveur

INRA (ed) (2018) INRA feeding system for ruminants. Wageningen Academic Publishers, The Netherlands

Institut National de Gestion et d'Economie Rurale (1989) Le mot juste: 250 termes et expressions pour analyser les résultats de gestion des exploitations agricoles. Paris, IGER, Paris

IPCC (2019) 2019 Refinement to the 2006 IPCC guidelines for national greenhouse gas inventories

Kingwell R (2011) Managing complexity in modern farming. Aust J Agric Resour Econ 55:12-34. https://doi.org/10.1111/j.1467-8489. 2010.00528.x

Kremen C, Iles A, Bacon C (2012) Diversified farming systems: an agroecological, systems-based alternative to modern industrial agriculture. Ecol Soc 17:44. https://doi.org/10.5751/ES-05103-170444

Laisse S, Baumont R, Dusart L et al (2018) L'efficience nette de conversion des aliments par les animaux d'élevage : une nouvelle approche pour évaluer la contribution de l'élevage à l'alimentation humaine. INRAE Prod Anim 31:269-288. https://doi.org/10.20870/ productions-animales.2018.31.3.2355

Latham LG (2006) Network flow analysis algorithms. Ecol Model 192: 586-600. https://doi.org/10.1016/j.ecolmodel.2005.07.029

Lau MK, Hines DE, Singh P, Borrett SR (2017) enaR: ecological network analysis with $\mathrm{R}$
Lê S, Josse J, Husson F (2008) FactoMineR : an R package for multivariate analysis. J Stat Soft 25. https://doi.org/10.18637/jss.v025.i01

Lemaire G, Franzluebbers A, Carvalho PC d F, Dedieu B (2014) Integrated crop-livestock systems: strategies to achieve synergy between agricultural production and environmental quality. Agric Ecosyst Environ 190:4-8. https://doi.org/10.1016/j.agee.2013.08. 009

Marley CL, Fraser MD, Davies DA, Rees ME, Vale JE, Forbes AB (2006) The effect of mixed or sequential grazing of cattle and sheep on the faecal egg counts and growth rates of weaned lambs when treated with anthelmintics. Vet Parasitol 142:134-141. https://doi. org/10.1016/j.vetpar.2006.06.030

Martel G, Guilbert C, Veysset P et al (2017) Effectively combining crop and livestock systems on conventional and organic farms: a means for increasing system sustainability? Fourrages:235-245

Martin G, Barth K, Benoit M, Brock C, Destruel M, Dumont B, Grillot M, Hübner S, Magne MA, Moerman M, Mosnier C, Parsons D, Ronchi B, Schanz L, Steinmetz L, Werne S, Winckler C, Primi R (2020) Potential of multi-species livestock farming to improve the sustainability of livestock farms: a review. Agric Syst 181:102821. https://doi.org/10.1016/j.agsy.2020.102821

Mischler P, Tresch P, Jousseins C, et al (2018) Savoir caractériser les complémentarités entre cultures et élevage pour accompagner la reconception des systèmes de polyculture-élevage dans leurs transitions agroécologiques. In: Reconception des systèmes d'élevage. Paris, France, pp 11-20

Mugnier S, Husson C, Cournut S (2020) Why and how farmers manage mixed cattle-sheep farming systems and cope with economic, climatic and workforce-related hazards. Renew Agric Food Syst 1-9. https://doi.org/10.1017/S174217052000037X

Nkurunziza L, Watson CA, Öborn I, Smith HG, Bergkvist G, Bengtsson J (2020) Socio-ecological factors determine crop performance in agricultural systems. Sci Rep 10:4232. https://doi.org/10.1038/ s41598-020-60927-1

Ognyanova K (2016) Network Analysis and Visualization with R and igraph

Pelletier P (2011) Contribution d'essais analytiques sur les prairies multiespèces à l'autonomie fourragère d'un système bovin viande naisseur-engraisseur biologique

Perrot C, Caillaud D, Chambaut H (2013) Économies d'échelle et économies de gamme en production laitière. Notes Études Socio Écon 30

Ponisio LC, M'Gonigle LK, Mace KC et al (2015) Diversification practices reduce organic to conventional yield gap. Proc R Soc B Biol Sci 282:20141396. https://doi.org/10.1098/rspb.2014.1396

Rufino MC, Hengsdijk H, Verhagen JMF (2009) Analysing integration and diversity in agro-ecosystems by using indicators of network analysis. Nutr Cycl Agroecosyst 84:229-247. https://doi.org/10. 1007/s10705-008-9239-2

Rutledge RW, Basore BL, Mulholland RJ (1976) Ecological stability: an information theory viewpoint. J Theor Biol 57:355-371. https://doi. org/10.1016/0022-5193(76)90007-2

Ryschawy J, Choisis N, Choisis J-P, Joannon A, Gibon A (2012) Mixed crop-livestock systems: an economic and environmental-friendly way of farming? Animal 6:1722-1730. https://doi.org/10.1017/ S1751731112000675

Ryschawy J, Joannon A, Gibon A (2014) Mixed crop-livestock farm: definitions and research issues. A review. Cah Agric 346-356. https://doi.org/10.1684/agr.2014.0727

Salmona M (1994) Les paysans français, les métiers, la transmission des savoirs, L'Harmattan

Smith L, Hicks J, Lusk S et al (2017) Does size matter? Animal units and animal unit months. Rangelands 39:17-19. https://doi.org/10.1016/ j.rala.2016.12.002

Stark F, Fanchone A, Semjen I, Moulin CH, Archimède H (2016) Croplivestock integration, from single practice to global functioning in 
the tropics: case studies in Guadeloupe. Eur J Agron 80:9-20. https://doi.org/10.1016/j.eja.2016.06.004

Stark F, González-García E, Navegantes L, Miranda T, Poccard-Chapuis R, Archimède H, Moulin CH (2018) Crop-livestock integration determines the agroecological performance of mixed farming systems in Latino-Caribbean farms. Agron Sustain Dev 38:11. https://doi. org/10.1007/s13593-017-0479-x

ten Napel J, van der Veen AA, Oosting SJ, Koerkamp PWGG (2011) A conceptual approach to design livestock production systems for robustness to enhance sustainability. Livest Sci 139:150-160. https:// doi.org/10.1016/j.livsci.2011.03.007

Vertès F, Jeuffroy M-H, Louarn G et al (2015) Legume use in temporary pastures: supplying nitrogen in crop-rotation system. Fourrages: $221-232$
Veysset P, Lherm M, Roulenc M, Troquier C, Bébin D (2015) Productivity and technical efficiency of suckler beef production systems: trends for the period 1990 to 2012. Animal 9:2050-2059. https://doi.org/10.1017/S1751731115002013

Watson CA, Atkinson D (1999) Using nitrogen budgets to indicate nitrogen use efficiency and losses from whole farm systems: a comparison of three methodological approaches. Nutr Cycl Agroecosyst 53: 259-267. https://doi.org/10.1023/A:1009793120577

Publisher's note Springer Nature remains neutral with regard to jurisdictional claims in published maps and institutional affiliations. 